تأثير التدريب بأسلوب المنافسة على بعض الخطط الهجومية الفردية لناشئى كرة القدم

د.محمد سعيد مصلحى محمد"

مشكلة البحث

تعتبر رياضة كرة القدم من الرياضـات الجماعية التى تأثرت بشــكل إيجــابى بتطـــور العلــوم

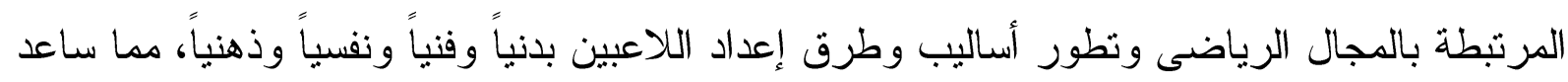
ذللك اللاعبين إلى الإرتقاء بمستوى الأداء وتحقيق التفوق و الإنجاز الرياضى.حيث تطورت اللعبة بشكل كبير عما كانت عليه سابقاً وفرض هذا التطور واجبات بدنية ومهارية وخططية عديدة ، كما أن تقارب

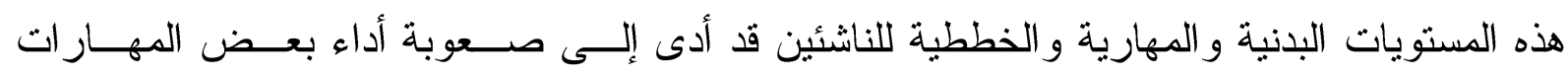
و الواجبات أثثاء المبار اة ، مما دفع المدربين و الباحثين و الدارسين و المهتمين بشئون اللعبة إلى الإهتمام بالبحوث و الدر اسات النظرية و التجريبية والبحث عن أساليب متتوعة ومتغيرة فى التدريب تشاعد على الى

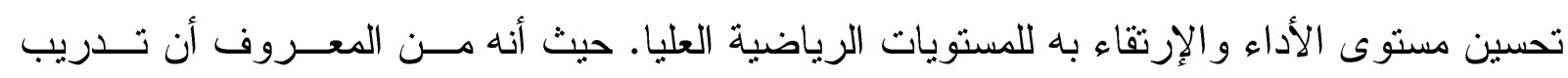

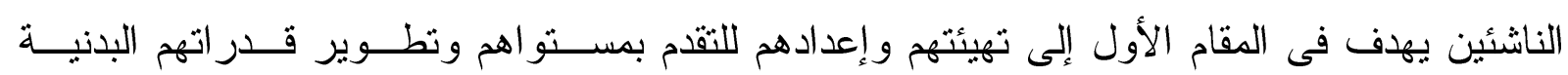
و المهارية و النفسية وفقاً لخصائص المرحلة السنية التي ينتمون إليها. ويذكر كلاً من إبراهيم شعلان وعمرو أبو المجد (1996م) ومحمد كثك وأمر الله البســاطى (2000م)وحسن أبو عبده (2008م) أن كرة القدم الحديثة يلعب فيهـــا الأداء الفنـى المميـز دوراً مهمافًي تحقيق نتائج ايجابية لصالح الفريق ويؤثر تأثيرًا مباشراً في عملية إتقان ونجاح الطريقة التي يلعب بها الفريق مما يؤدى إلى إرباك المنافس و عدم قدرته في السيطرة على مجريات اللعب و الأداء.

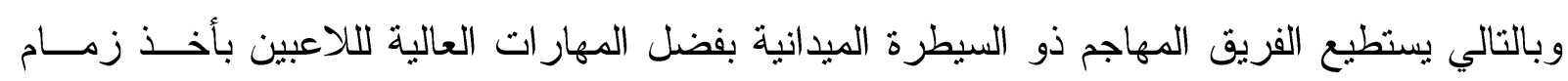
المبادرة والقدرة على الهجوم و الوصول إلى مرمى المنافس وإحراز الأهداف. وكلما زادث درجة إتقان اللاعب للمهار ات الهجومية والدفاعية كلما اسنطاع تركيز الجزء الأكبر من عمليات التفكير في خطط اللعب بشقيها، كما أن إتقان اللاعب للمهار ات هام ورئيسي لتتفيذ وظائف اللعب بشكل سليم وفعال كما

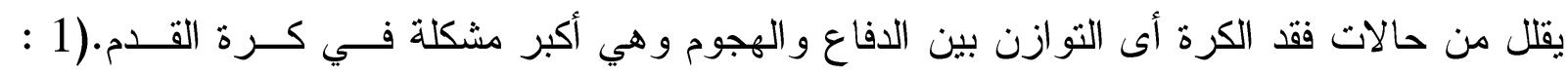
(27:4)(210:8)(18

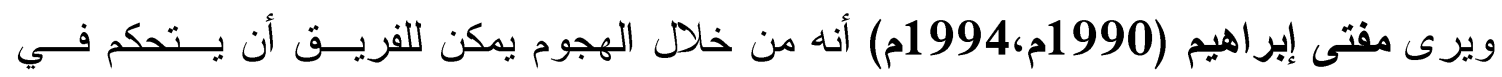

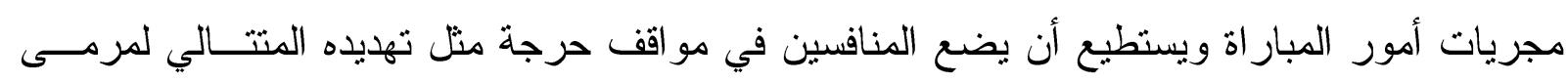

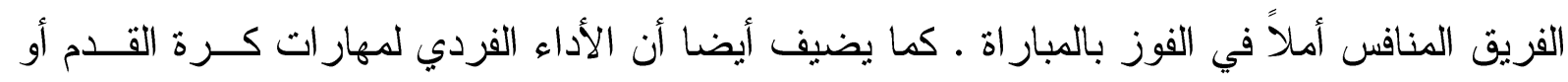

"مدرس بقسم نظريات وتطبيقات الرياضات الجماعية ورياضات المضرب ـ كلية التربية الرياضية -جامعة بنها

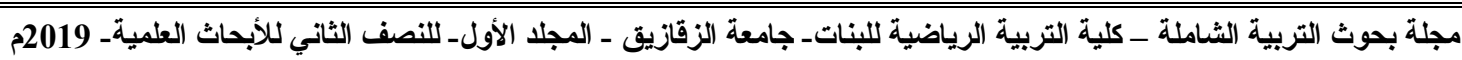


$-323-$

تأثير التذريب بأسلوب المنافسة على بعض الخطط الهجومية الفردية لناثئيى كرة القدم

تحركات اللاعب الفردية لاغني عنها في تتفيذ خطط اللعب الهجومية إذ يعتبر إتقانهـا عــاملاً مهمــاً وضرورياً لإنجاح تلأك الخطط وهى تعتبر بمثابة الوسائل الأساسية في تتفيذ خطط اللعــب الهجوميــة و هذه الوسائل هي: التصويب ، المراوغة ، الجري بالكرة ،التحركات الفعالة للاعب. ( 10: 131)

ويرى كلاً من فلاديمير وأخرون Vladimir.etal (2001م) ، بر ايد 2004م) (أنه من

أولى خطو ات المدرب عندما يقود فريق هى التخطيط للبرنامج التدريبى مع مر اعاة المرحلــة الســنيه و المستوى البدنى و المهارى و الخططى وعدد مرات التدريب الأسبو عية وزمن الوحدة وتوقيت التدريب و عدد الأسابيع ثم إختيار التدريبات التى تتناسب مع قدرات الناشئين حتى لا يتعرضون للإجهاد ومن ثم هبوط المستوى و البعد عن الهدف المراد تحقيقه ، و الوصول بالبرعم إلى الأداء الرياضى الجيد يتطلب

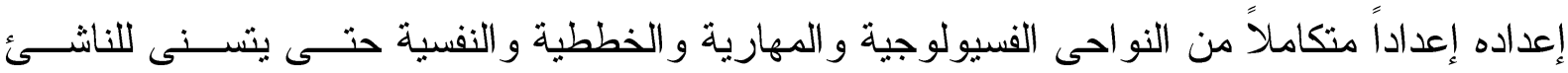

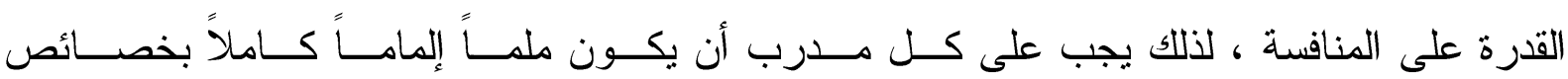

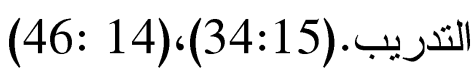

ويضيف كلاً من رائد صقر(2015م) ، وسام طعيمه(2016م)أن أسلوب المنافسة أحد الأساليب التى تشاعد علي التقدم بالمستوي المهاري و البدني في نوع النشاط الرياضي فــلا يخلــو أي نشـــاط رياضي من المنافسة سواء جماعي أو فردي حيث يعتبر نوع من أنواع الإختبار لكفاءة الفرد و استيعابه للمهار ات و التدريب حيث بساهم في معرفة الفرد لمستو اه بالنسبة لمنافسيه، وتمرينات المنافسة كثــكل تدريبي يهدف إلي الارتقاء بمستوي أداء المبار اة فهي تتشابه مع المبار اة إلا أنها تختلف عنها في بعض خصائص الأداء إذ ان الهدف الرئيسي من أدائها هو التدريب علي أسلوب أداء المبار اة والتدريب علي

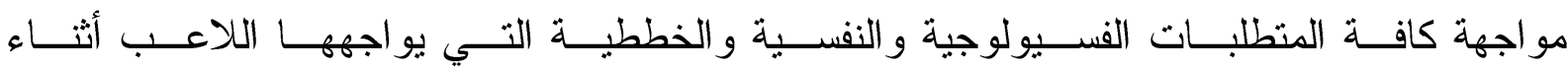

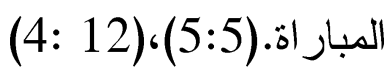

و أسلوب المنافسةيهدف إلى الجمع بين تعلم أداء اللعب الخططي وتطوير المهار ات الفردية مــن خلال تطوير القدرة على استخدام المهار ات الأساسية وممارسـتها فـي حــالات مشـــابهة لحــالات اللعب.ولذلك لابد من توفير بيئة للتدريب على المهار ات الأساسية وبنفس الوقت تطبيقها فـي حـالات لعب و اقعية، و الابتعاد عن بعض الأساليب القديمة التي تعتمد على تدريب المهار ات و إتقانها ثم تعلــم خطط اللعب بالتعاقب، لذا يتجه المدرب إلى تعليم اللاعبين كيفية استخدام تلك المهار ات في أثناء اللعب من خلال تتفيذ هذه المهار ات ضمن واجبات خططية " تمرينات خططية مهارية معا "، مدـــا يعطـي للاعب الفرصة لبناء برنامج حركي متكامل للمهار ات و استيعاب كيفية استخدامها فى التوقيت الصحبح 
و السيطرة والتحكم بالأداء أثناء مجريات اللعب، وهذا لا يمكن الوصول إليه إلا من خلال الحالات التى مرت على اللاعب أثناء أدائه التمرينات الخططية. ومن خلال متابعة الباحث للعديد من المباريات و التدريبات المختلفة ومن خلال خبرات الباحسـ

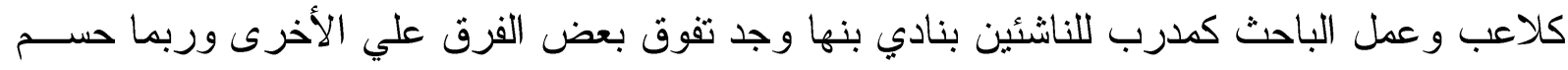

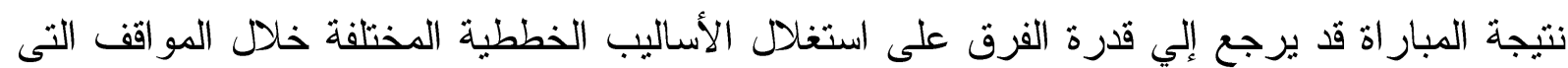

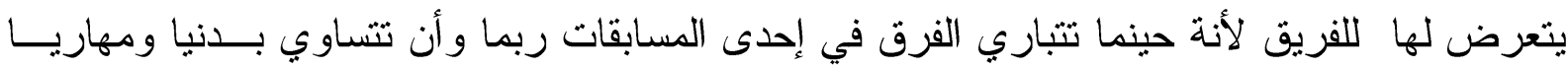

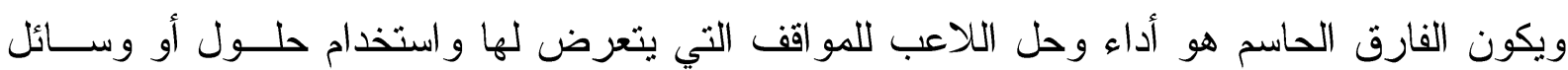

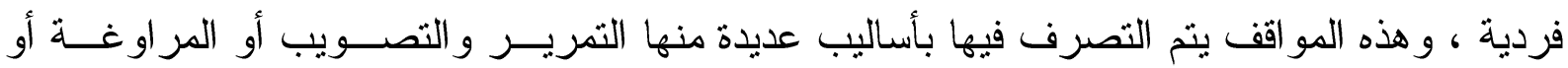

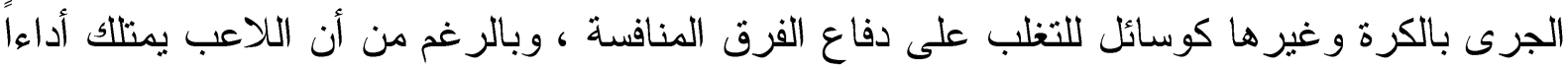

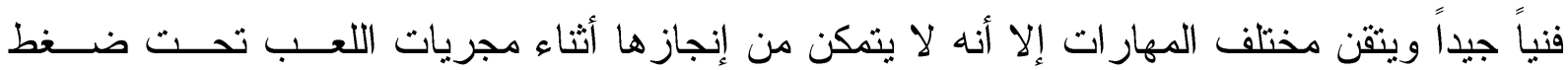

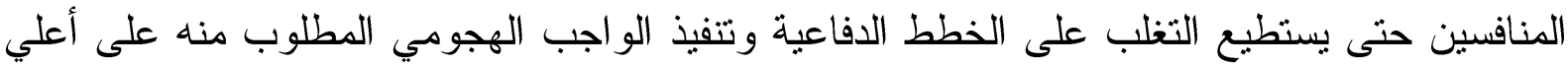

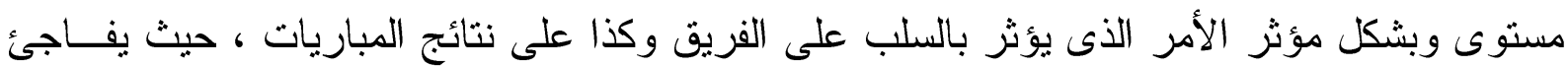
اللاعب بالمو اقف التى تفرض عليه أثناء المنافسة فلا يجيد التصرف فيها بشكل سليم، ويرى الباحث أن

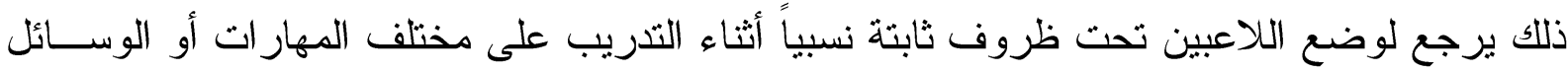
الهجومية الفردية فمو اقف اللعب المتتوعة التى تتغير أحداثها بإستمر ار تفرض على اللاعبين اســتخدام

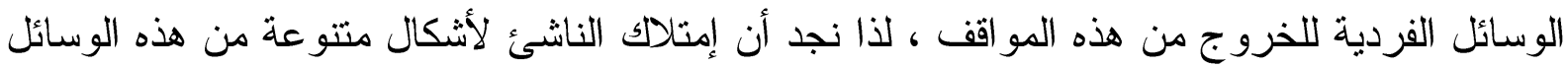

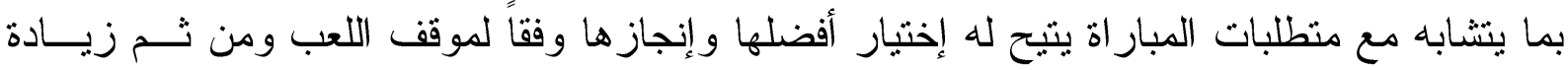

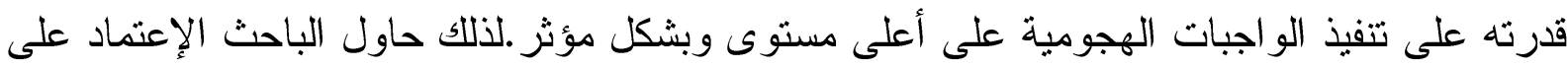

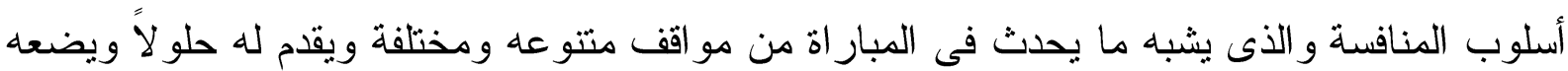
تحت ضغط المنافس خلال المبار اة أو التنريب وفى نفس ظروف المبار اة و هذا ما يتطابق ومنطلبـات اللعب الحديث للناشئين ، من هنا ظهرت مشكلة البحث و هذا ما وجــه نظـــر الباحــث لاســتخدامهذا

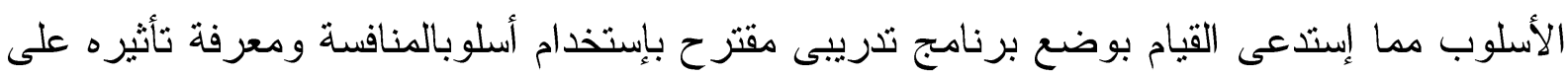
بعض الخطط الهجومية الفردية لناشئى كرة القدم .

\section{هدف البحث:}

التعرف على نأثير التدريب بأسلوب المنافسة على بعض الخطط الهجومية الفردية لناشئى كـرة القدم ويتحقق هذا الهذف من خلال:

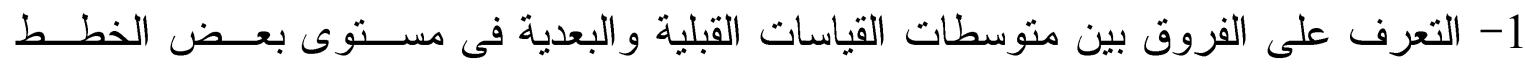
الهجومية الفردية لناشئى كرة القدم للمجموعة التجريبية قيد البحث. 
2- التعرف على نسب التحسن بين متوسطات القياسات القبلية و البعدية فى مستوى بعض الخطط الهجومية الفردية لناشئى كرة القدم للمجموعة التجريبية قيد البحث.

\section{فروض البحث:}

1- توجد فروق إحصائية ذات دلالة معنوية بين متوسطات القياسات القبلية و البعديــة للمجموعــة

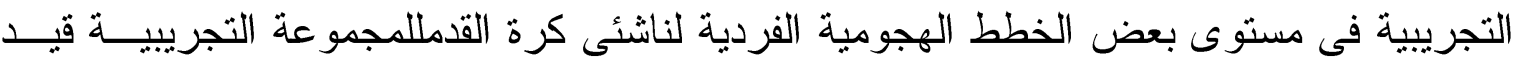
البحث ولصالح منوسطات القياسات البعدية. 2- توجد نسب تحسن بين متوسطات القياسات القبلية و البعدية للمجمو عة التجريبية فـى مسـتوى بعض الخطط الهجومية الفردية لناشئى كرة القدم للمجموعة التجريبية قيد البحث. مصطاح البحث:

1- أســلوب المنــافسة:هو شكل تدريبي ينفذ خلال التدريب في وجود مدافع إيجابي يحــاول قطــع و استخلاص الكرة ويساهم في تطوير مستوي وسرعة الأداء، ويعتبر نوع من أنواع الاختبار ويشبه ما يحدث خلال المباريات (موقف حقيقي).(") 2- الخطط الهجومية الفردية: هو الأداء الذى يقوم به لاعب بغرض هجومي لتنفيذ واجبات مركـزه

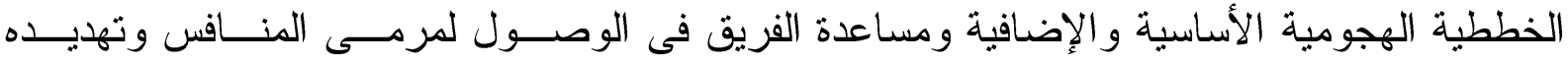
،كالتمرير و التصويب و المراوغة و الجرى بالكرة و التحرك بدون كرة.(10: 5) •

\section{• منهج البحث}

استخدم الباحث المنهج التجريبى لمناسبته لطبيعة البحث بإستخدام التصميم التجريبى لمجموعة واحــده

$$
\text { • مجتمع البحدام القياس (القبلى - البعدى). }
$$

يتكون مجتمع البحث من ناشئى كرة القدم بمحافظة القليوبية تحث (20سنه ) ، و البــالغ عـددهم (8) فرقو المشاركين بدورى منطقة القليوبية لكرة القدم موسم 2019م - 2020م. • عينة البحث قام الباحث بإختيار عينة البحث بالطريقة العمدية ، من ناشئى كرة القدم بنادى بنها تحت (20سنه ) ، و البالغ عددهم (23) ناشئى ، وتم استبعاد (4) ناشئين من بينهح حارسى مرمى ولاعبين لعدم انتظامهم فى التدريب. ليكون العدد النهائى 19 ناشئى. 
$-326-$

تأثير التثريب بأسلوب المنافسة على بعض الخطط الهجومية الفردية لناشئى كرة القام

•توصيف مجموعتى البحث (التجريبيةو الإستطلاعية)

جدول (1)

توصيف مجموعتى البحث

\begin{tabular}{|c|c|c|c|}
\hline النسبة المئوية & 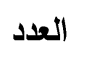 & التصنيف & p \\
\hline 54.29 & 19 & المجــــــوعة التجريبية & 1 \\
\hline 45.71 & 16 & المجموعة الإسنطلاعية & 2 \\
\hline$\% 100$ & 35 & & \\
\hline
\end{tabular}

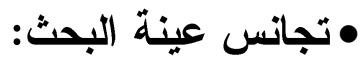

جدول (2)

تجانس عينة البحث التجريبية فى خصائص النمو

$19=\dot{0}$

\begin{tabular}{|c|c|c|c|c|c|}
\hline الالتواء & الوسيط & $\varepsilon^{ \pm}$ & سَ & وحدة القياس & المتغيرات \\
\hline 1.01 & 176 & 1.49 & 176.5 & سم س س & الطول \\
\hline $0.35-$ & 73.5 & 2.55 & 73.2 & كجم & الوزن \\
\hline 1.03 & 19.4 & 0.87 & 19.7 & سنة & العمر الزمنى \\
\hline $0.68-$ & 5.8 & 1.32 & 5.5 & سنة & العمر التتريبي \\
\hline
\end{tabular}

يوضح جدول (2) أن معامل الالنو اء لخصائص النمو للناشئين تحت 20 سنة تتحصر بين 3 مما يشير إلى

تجانس العينة التجريبية.

جدول (3)

تجانس عينة البحث التجريبية فى بعض الإختبارات البدنية

$19=\dot{0}$

\begin{tabular}{|c|c|c|c|c|c|c|}
\hline الالتواء & الوسيط & $\varepsilon \pm$ & سَ - س & وحدة القياس & الصفة & الإختبار ات \\
\hline 0.45 & 4.30 & 1.60 & 4.54 & ثانيه & سرعة انتقالية & إختبارعدو30م من الوقوف \\
\hline $1.31-$ & 26.64 & 0.94 & 26.23 & ثانيه & تحمل سرعة & إختبار جرى (30م X 5مرات تكرار) \\
\hline $1.86^{-}$ & 20.88 & 1.29 & 20.08 & ثانيه & رشاقة & إختبار الجرى الزجزاجى (بارو ) \\
\hline 0.09 & 10.38 & 1.70 & 10.43 & عدد & سرعة أداء & إختبار تمرير الكرة على مقعد سويدى(10ث) \\
\hline 0.11 & 33.07 & 2.14 & 33.15 & عدد & تحمل أداء & ضرب الكرة بالقدم والر أس لمدة دقيقة \\
\hline
\end{tabular}

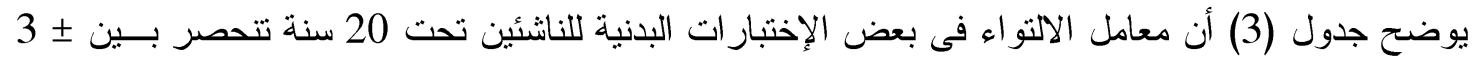

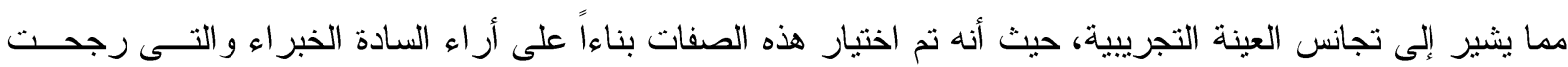
هذه الصفات و المرتبطة ارتباط وثيق بموضوع لجنئه البحث. 
$-327-$

تأثير التّريب بأسلوب المنافسة على بعض الخطط الهجومية الفردية لناشئى كرة القدم

جدول (4)

تجانس عينة البحث التجريبية فى بعض الخطط الهجومية الفردية

$19=\dot{ن}$

\begin{tabular}{|c|c|c|c|c|c|c|}
\hline الالتواء & الوسيط & $\varepsilon^{ \pm}$ & سَ & وحدة القياس & 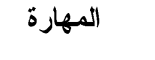 & الإختبار ات \\
\hline 0.32 & 3.50 & 2.44 & 3.76 & درجة & التمرير & إختبار دقة التمرير القصير \\
\hline $1.62-$ & 36.50 & 2.19 & 35.32 & 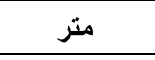 & التصويب & إختبار ركل كرة ثابتة لأبعد مسافة \\
\hline 0.71 & 5.57 & 1.39 & 5.90 & ثانية & الجرى بالكرة & اختبار الجرى بالكرة فى خط مستقيم (25م) \\
\hline $0.19-$ & 12.43 & 1.77 & 12.32 & ثانية & المر اوغة & اختبار الجرى الزجزاجى بين الأقماع 20م \\
\hline
\end{tabular}

يوضح جدول (4) أن معامل الالتو اء فى بعض الخطط الهجومية الفردية للناشئين تحت 20 سنة تتحصر بــين

It 3 مما يشير إلى تجانس العينة التجريبية.

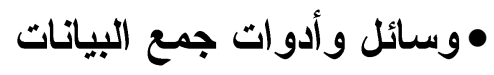

• المسع المرجعى

•المسح المرجعى للإختبار ات البدنية مرفق(2)

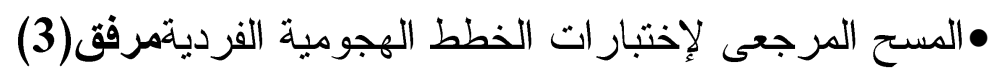

•استطلاع ر أى الخبر اء للإختبار ات البدنية المرتبطة بالخطط الهجومية الفردية

• الإختبار ات البدنية

قام الباحث بالإطلاع على المر اجع و الدراسات العلمية فى كرة القدم، ونوصل الباحث من خلال المسح المرجعى إلى الإختبار ات التالية مرفق (4) وتم عرضها على السادة الخبر اء لترجيح الصفات المرتبطة ارتباط وثيق ببعض الخطط الهجومية الفردية و استطلاع ر أيهح و الجدول رقـــ (5) يوضـــح النتــائج النهائية لأز اء السادة الخبر اءئ

جدول (5)

النتائج النهائية لأراء السادة الخبراء فى الإختبارات البلنية المرتبطة ببعض الذطط الهجومية الفردية فى البحث

\begin{tabular}{|c|c|c|}
\hline وحده القياس & الغرض من الإختبار & الإختبار ات \\
\hline ثانيه & سرعة انتقالية & إختبار عدو30م من الوقوف \\
\hline ثانيه & تحمل سرعة & إختبار جرى (30م X 5مرات تكرار) \\
\hline ثانيه & رشاقة & إختبار الجرى الزجزاجى (بارو ) \\
\hline عدد & سرعة أداء & إختبار تمرير الكرة على مقعد سويدى(10ث) \\
\hline عدد & تحمل أداء & ضرب الكرة بالقدم والر أس لمدة دقيقة \\
\hline
\end{tabular}


قام الباحث بالإطلاع على المر اجع و الدراسات العلمية فى كرة القدم، وتوصل الباحث من خلال المسح المرجعى إلى الإختبار ات الثالية مرفق (5) ،وتم عرضها على السادة الخبراء لإختيــار الإختبـار ات الات

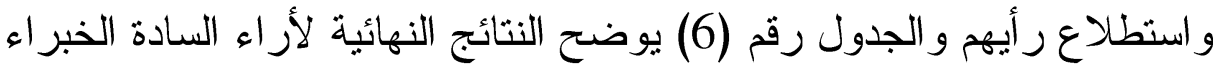
جدول (6)

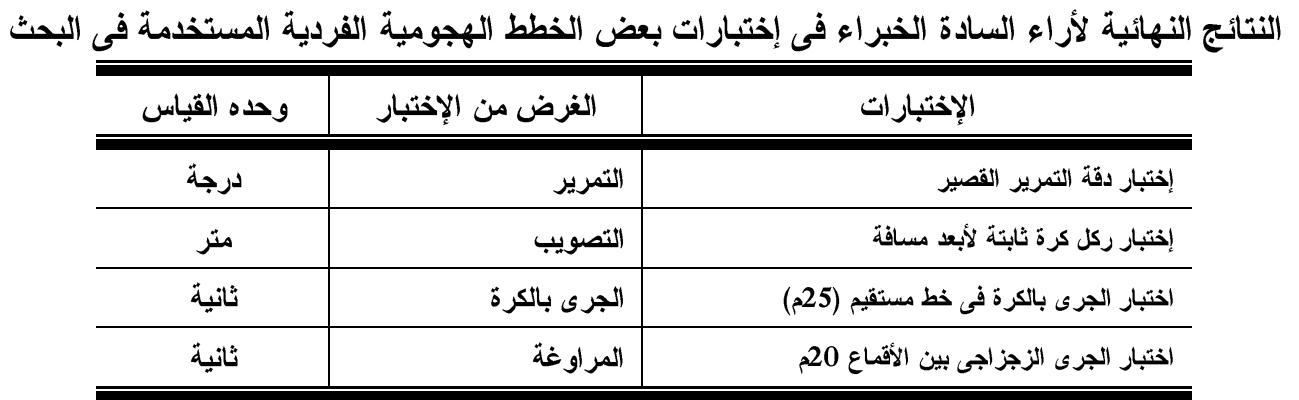

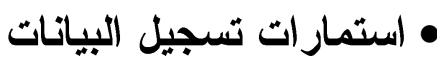

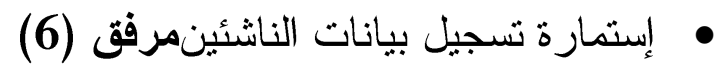

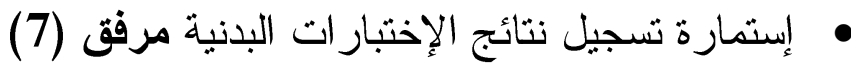

إستمارة تسجيل نتائج إختبار ات بعض الخطط الهجومية الفرديةمرفق (8) • الأجهزة المستخدمه فى القياسات الخاصة بالبحث

$$
\text { •شاعة إيقاف. }
$$

• الأدوات المساعدة فى القياسات و البرنامج التدريبى الخاصة بالبحث

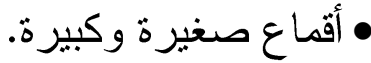

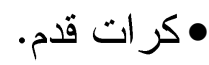

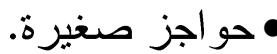

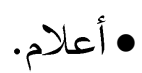

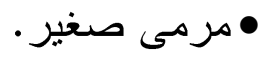

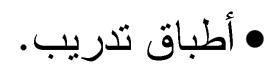

• • ملم تو افقى.

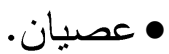

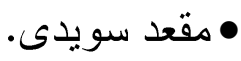

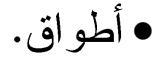

• الادر اسات الإستطلاعية

• الار اسة الإستطلاعية الأولى الإسطاعه

- قام الباحث بإجر اء الدر اسة الإستطلاعية الأولى خلال الفترة من يوم الاثثين (2019/7/15م) وذلكك

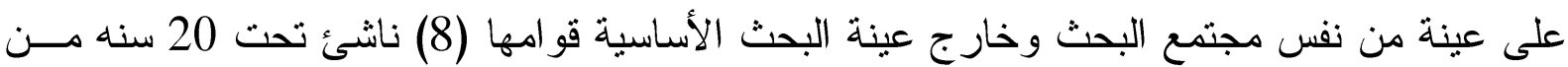

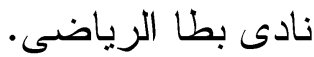




\section{• أهداف الاراسة الإستطلاعية الأولى}

• إعداد مكان التدريب وتنظيم الملعب.

ه التأكد من صلاحية الأدوات و الأجهزة المستخدمه.

تدريب المساعدين على كيفية إجر اء الإختبار ات.

مدى ملائمة الإختبار ات لعينه البحث.

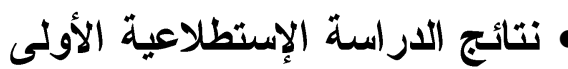

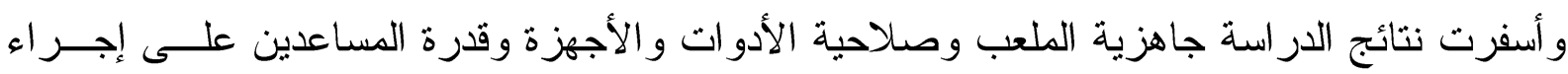
الإختبار ات ومناسبة الإختبار ات لعينة البحث.

• الدار اسة الإستطلاعية الثانية

- قام الباحث بتطبيق الدراسة الاسنطلاعية الثانية على نفس عينة الدراسة الاستطلاعية الأولى ، فـى لـى

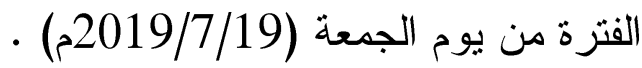
•أهداف الاراسة الإستطلاعية الثانية

•مراجعة الشروط النهائية الخاصة بتطبيق الإختبار ات.

•مدى إستبعاب المساعدين لطريقة إجر اء الإختبار ات. • إكتشاف الصعوبات و المعوقات التى قد تظهر خلال التطبيق. • نتائج الاراسة الإستطلاعية الثانية

و أسفرت نتائج الدر اسة الإلمام بكيفية تطبيق وشروط كل الإنطيه التبار و استيعاب المساعدين لطريقة إجــر اء الإختبار ات و التظلب على كل الصعوبات التى قد تظهر خلال الدراس اسة أو التطبيق.

\section{• المعاملات العلمية للإختبارات

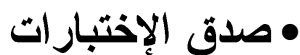

قام الباحث بايجاد معامل الصدق للإختبار ات البدنية وبعض الخطط الهجومية الفردية المستخدمة ، حيث قام الباحث بالإستعانة بعينة عددها (8) ناشئين تحت (20) سنة (مجموعة مميزة) وكذلك عدد التهاد

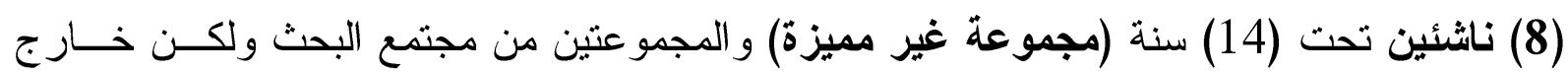

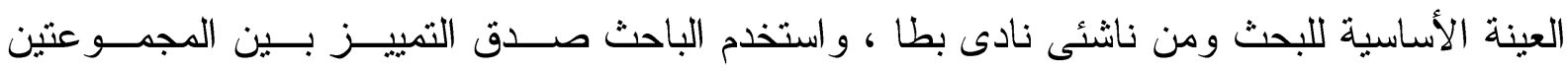

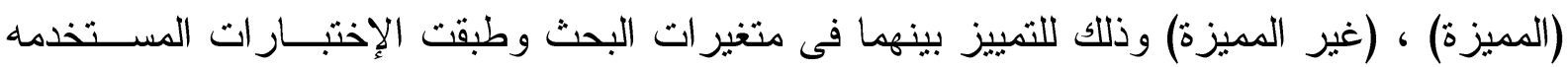

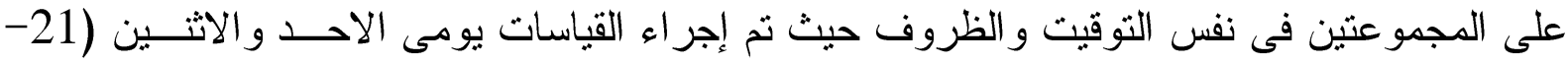

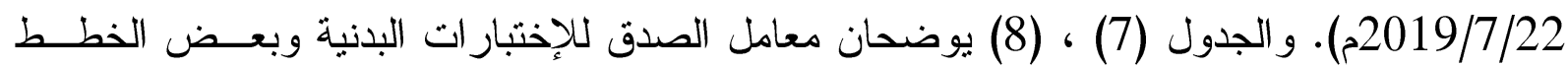
الهجومية الفردية المستخدمة. 
$-330-$

تأثير التثريب بأسلوب المنافسة على بعض الخطط الهجومية الفردية لناشئى كرة القام

جدول (7)

معامل الصدق للإختبارات البدنية المستخدمة

$8=2 ن=1$ ن

\begin{tabular}{|c|c|c|c|c|c|c|}
\hline \multirow{2}{*}{ قيمة } & \multicolumn{2}{|c|}{ مجموعة غير مميزة } & \multicolumn{2}{|c|}{ مجموعة مميزة } & \multirow{2}{*}{ القياس } & \multirow{2}{*}{ 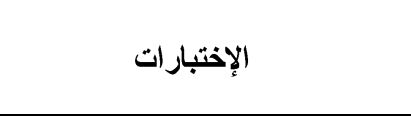 } \\
\hline & $\varepsilon \pm$ & سَ س & $\varepsilon \pm$ & 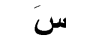 & & \\
\hline *3.43 & 1.54 & 5.43 & 0.65 & 4.80 & ثانيه & إختبارعدو30م من الوقوف \\
\hline$* 3.77$ & 0.80 & 27.39 & 1.22 & 26.43 & ثنانيه & إختبار جزى (30 مX 5مرات تكرار) \\
\hline$* 2.80$ & 2.77 & 21.22 & 2.40 & 20.54 & ثانيه & إختبار الجرى الزجزاجى (بارو ) \\
\hline *5.08 & 1.08 & 6.25 & 2.98 & 10.83 & عدد & إختبار تمرير الكرة على مقعد سويدى(10ث) \\
\hline *7.11 & 2.32 & 23.54 & 1.07 & 33.59 & عدد & ضرب الكرة بالقدم والر أس لمدة دقيقة \\
\hline
\end{tabular}

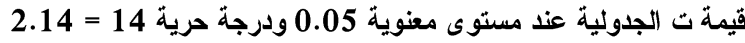

يتضح من جدول (7) أن قيمة ت المحسوبة إنحصرت بين (2.80:7.11) بين المجموعتين المميزة وغير المميزة وكاتت قيمنها أكبر

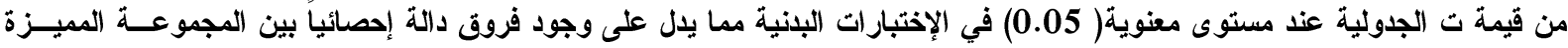

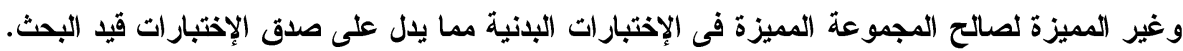

جدول (8)

معامل الصدق لإختبارات الخطط الهجومية الفردية المستخذمة

$8=2 \dot{ن}=1$ ن

\begin{tabular}{|c|c|c|c|c|c|c|}
\hline \multirow{2}{*}{ تيمة } & \multicolumn{2}{|c|}{ مجموعة غير مميزة } & \multicolumn{2}{|c|}{ مجموعة مميزة } & \multirow{2}{*}{ وحده } & \multirow{2}{*}{ الإختبار ات } \\
\hline & $\varepsilon \pm$ & سَ س & $\varepsilon^{ \pm}$ & 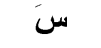 & & \\
\hline$* 3.12$ & 2.45 & 2.86 & 2.12 & 3.78 & درجة & إختبار دقة التمرير القصير \\
\hline *5.55 & 0.62 & 30.21 & 1.55 & 35.97 & 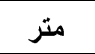 & إختبار ركل كرة ثابتة لأبعد مسافة \\
\hline$* 3.70$ & 1.55 & 6.80 & 1.27 & 5.48 & ثانيه & اختبار الجرى بالكرة فى خط مستقيم (25م) \\
\hline *3.38 & 3.13 & 11.75 & 2.30 & 12.11 & ثانيه & اختبار الجرى الزجزاجى بين الأقماع 20م \\
\hline
\end{tabular}

قيمة ت الجدولية عذد مستوى معنوية 0.05 ودرجة حرية 14 = 2.14

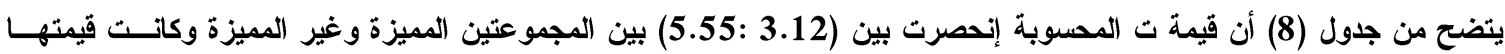

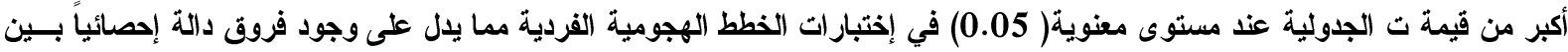
المجموعة المميزة وغير المميزة لصالح المجموعة المميزة فى إختبارات الخطط الهجومية الفرديةمما يدل على صدق الإختبارات قيد البحث. • مثبات الإختبار ات

ثم ثام الباحث بإيجاد معامل الثبات (الارتباط) بأسلوب تطبيق الاختبار ثم إعادة تطبيقه ( Test (Retest بفاصل زمنى قدرة أربعة أيام بين التطبيقين الأول و الثاني، قام الباحث بالاســتعانة بالعينــة السابقة و التي طبقت عليها الدر اسة الإستطلاعية الأولى و الثانية و عددها (8) ناشئين من لاعبي نـادي بطا الرياضي تحث 20 سنه ولكن خارج العينة الأساسية للبحث، حيث أجـرى القبــاس الأول بـوم الاربعاء (2019/7/24) و القياس الثاني يوم الاثثين (2019/7/29م)، وتم حساب معامل الارثبـاط لبيرسون بين نتائج القياسين الأول و الثاني. 
$-331-$

تأثير التثريب بأسلوب المنافسة على بعض الخطط الهجومية الفردية لناشئى كرة القام

جدول (9)

معامل الثبات لنتائج الإختبارات البذنية المستخدمه

\begin{tabular}{|c|c|c|c|c|c|c|}
\hline \multirow{2}{*}{ معامل الإرتباط } & \multicolumn{2}{|c|}{ القياس الثاني } & \multicolumn{2}{|c|}{ القياس الأول } & \multirow{2}{*}{ وحدة } & \multirow{2}{*}{ الإختبار ات } \\
\hline & $\varepsilon \pm$ & سن & $\varepsilon \pm$ & سن & & \\
\hline *0.876 & 1.22 & 4.65 & 2.07 & 4.48 & ثانيه & إختبارعدو30م من الوقوف \\
\hline$* 0.769$ & 2.39 & 26.43 & 2.39 & 26.30 & ثانيه & إختبار جرى (30م X 5مرات تكرار) \\
\hline * 0.770 & 2.82 & 20.15 & 1.77 & 20.53 & ثانيه & إختبار الجرى الزجزاجى (بارو ) \\
\hline * 0.754 & 0.77 & 10.54 & 2.54 & 10.05 & عدد & إختبار تمرير الكرة على مقعد سويدى(10ث) \\
\hline$* 0.807$ & 1.38 & 33.59 & 1.48 & 33.19 & عدد & ضرب الكرة بالقدم والر أس لمدة دقيقة \\
\hline
\end{tabular}

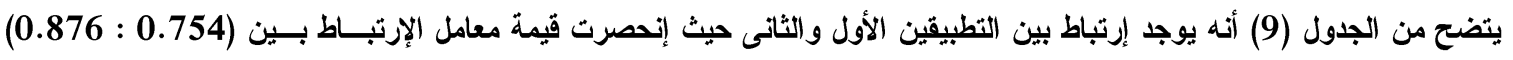

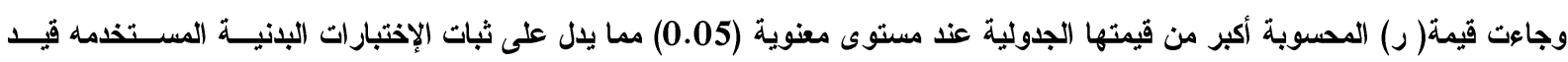

جدول (10)

معامل الثبات نتتائج اختبارات بعض وسائل تنفيذ الخطط الهجومية الفردية المستخدمه ن=8)

\begin{tabular}{|c|c|c|c|c|c|c|}
\hline \multirow{2}{*}{ الإرتباط معامل } & \multicolumn{2}{|c|}{ القياس الثاني } & \multicolumn{2}{|c|}{ القياس الأول } & \multirow{2}{*}{ وحدة } & \multirow{2}{*}{ 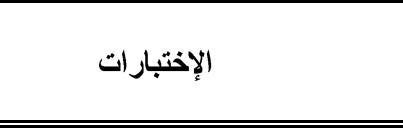 } \\
\hline & $\varepsilon \pm$ & سَ & $\varepsilon \pm$ & سَ & & \\
\hline$* 0.793$ & 1.11 & 3.19 & 2.04 & 3.21 & درجة & إختبار دقة التمرير القصير \\
\hline * 0.777 & 2.03 & 35.53 & 1.30 & 35.30 & مثر & إختبار ركل كرة ثابتَّة لأبعد مسافة \\
\hline *0.812 & 2.59 & 5.36 & 1.77 & 5.19 & ثانية & اختبار الجرى بالكرة فى خط مستقيم (25م) \\
\hline * 0.855 & 1.18 & 12.22 & 2.32 & 12.65 & ثانية & اختبار الجرى الزجزاجى بين الأقماع 20م \\
\hline
\end{tabular}

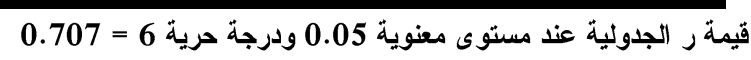

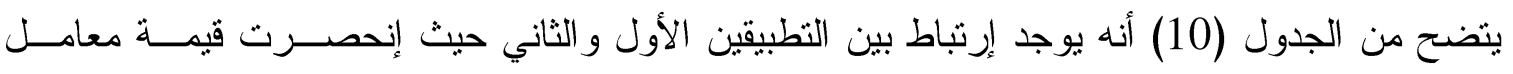
الإرنباط بين (0.777 : 0.855) وجاءت قيمة (ر) المحسوبة أكبر من قيمتها الجدولية عند مستوى معنويــة (0.05) مما يدل على ثبات اختبار ات بعض الخطط الهجومبة الفردية المستخدمة قبد البحث. • - إختيار المساعدين

قام الباحث بالإستعانة بمجمو عة من المساعدين و الذين تم اختيار هم لمساعده الباحث فى القياسات

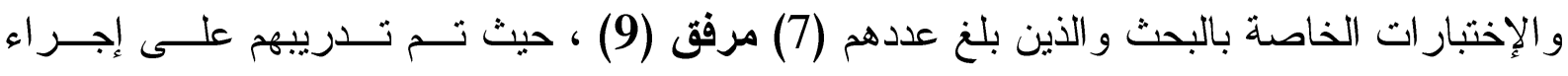
القياسات وكيفية أداء الإختبار ات وحساب الدرجات و الهدف من كل إختبار بالإضـافة إلــى تزويــــهم

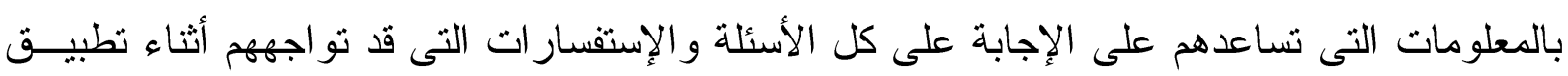
القياسات والإختبار ات خلال الدر اسات الإستطلاعية أو خلال القياسات الخاصة بالدر اسة .

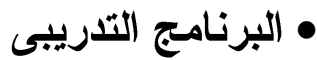

يهدف البرنامج التذريبى إلى استخدام أسلوب المنافسة لتحسين بعض الخطط الهجومية الفرديـة لناشئى كرة القدم.ومن خلال المسح المرجعى للمر اجع العلمية والبحوث السابقة استطاع الباحث تحديد 


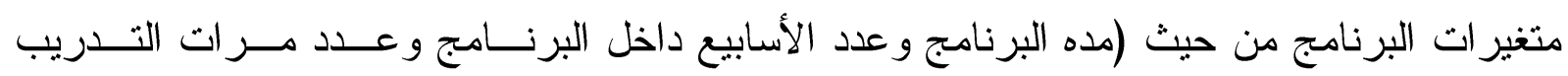

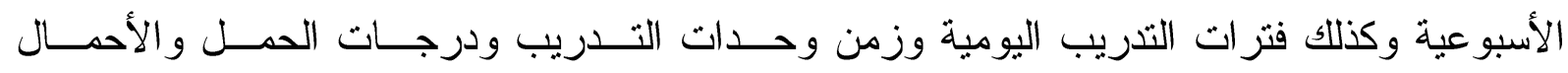

المستخدمة) ووضع البرنامج فى صورته النهائية.

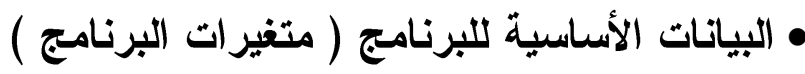

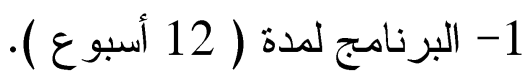

2- المرحلة السنية تحت 20 سنة.

3- نوقيت البرنامج (خلال فترة الإعداد).

4- مكان تطبيق البرنامج (نادى بنها الرياضى).

5- عدد وحدات التدريب الأسبو عية (4 وحدات)(الأحد - الإثثين - الأربعاء - الخميس).

6- عدد مرات التدريب اليومية ( مرة و احدة فقط ).

7- عدد وحدات البرنامج ( 48 و وحده ).

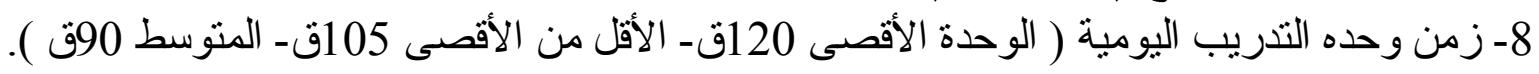

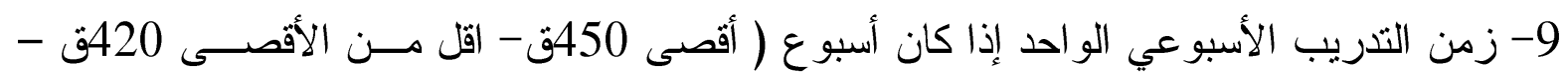

متوسط 390ق).

10- زمن البرنامج ككل ( 5040 دقيقة ).

11- الأحمال المستخدمة داخل تدريبات البرنامج (أقصى - أقل من الأقصى - منوسط) )

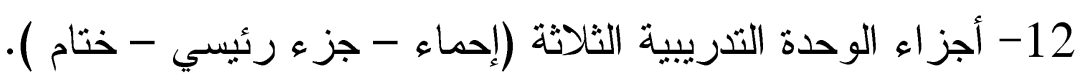

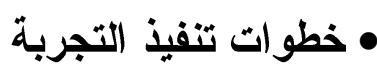

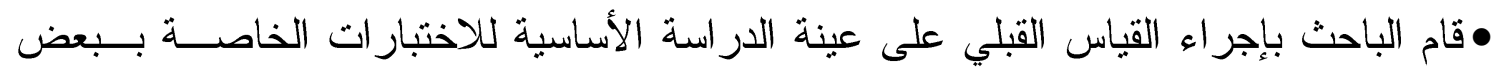

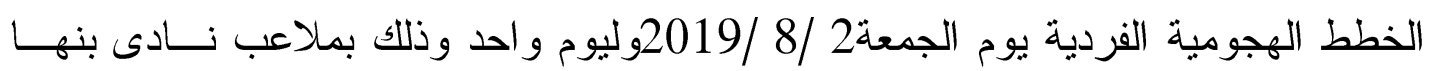

$$
\text { الرياضي. }
$$

•تم تنفيذ البرنامج التدريبي المقترح على بعض وسائل تتفيذ الخطط الهجومية الفردية لناشــئ

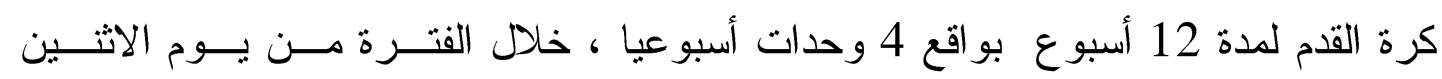
2019/8/5م وحتى السبت2019/10/26م ،.وذلك بملاعب نادى بنها الرياضي.

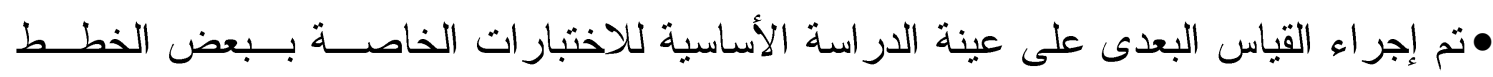
الهجومية الفردية يوم الثلاثاء29 /

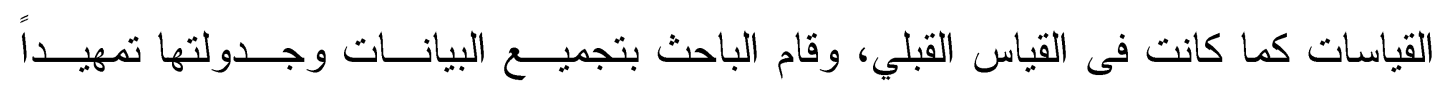

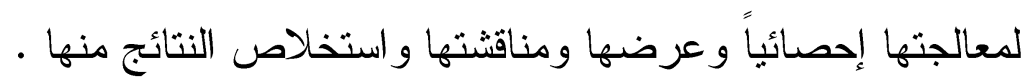




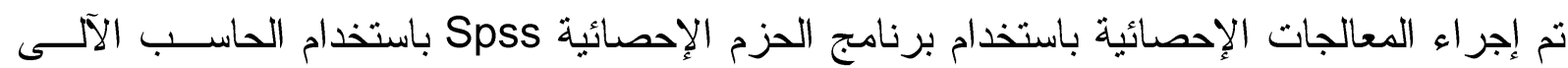
وذللك من خلال المعالجات الإحصائية التالية

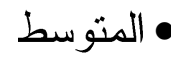

$$
\begin{aligned}
& \text { • الوسيط } \\
& \text { •الإنحر اف المعيارى } \\
& \text { • •معامل الالتو اء الاء } \\
& \text { • } \\
& \text { • معامل الإرتباط لبيرسون } \\
& \text { • نسب التحسن } \\
& \text { • عرض النتائج ومناقشتها }
\end{aligned}
$$

\begin{tabular}{|c|c|c|c|c|c|c|}
\hline \multirow{2}{*}{ قيمة } & \multicolumn{2}{|c|}{ القياس البعدى } & \multicolumn{2}{|c|}{ القياس القبلى } & \multirow{2}{*}{ وحداه } & \multirow{2}{*}{ الإختبار ات } \\
\hline & $\varepsilon \pm$ & س س & $\varepsilon \pm$ & سَ & & \\
\hline * 4.38 & 1.30 & 5.56 & 1.55 & 3.32 & ل درجة & إختبار دقة التمرير القصير \\
\hline *3.27 & 0.76 & 38.45 & 2.68 & 35.14 & درجة & إختبار ركل كرة ثابتة لأبعد مسافة \\
\hline *2.64 & 1.11 & 5.10 & 2.20 & 5.85 & ثانيه & اختبار الجرى بالكرة فى خط مسنقيم (25م) \\
\hline *3.10 & 2.06 & 11.21 & 1.58 & 12.32 & ثانيه & اختبار الجرى الزجزاجى بين الأقماع 20م \\
\hline
\end{tabular}

جدول (11)

دلالة الفروق بين متوسطات القياسات القبلية والبعديةفى بعض الخطط الهجومية الفردية لعينة البحث

$19=\dot{0}$

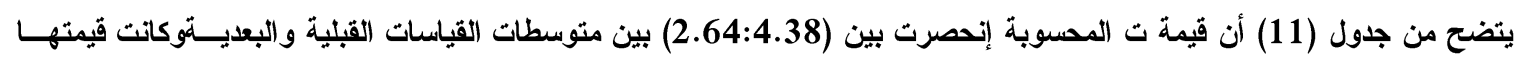

\begin{tabular}{|c|c|c|c|c|c|c|}
\hline \multirow{2}{*}{ التحسن \% } & \multicolumn{2}{|c|}{ القياس البعدى } & \multicolumn{2}{|c|}{ القياس القبلى } & \multirow{2}{*}{ وحده } & \multirow{2}{*}{ الإختبارات } \\
\hline & $\varepsilon^{ \pm}$ & س & $\varepsilon^{ \pm}$ & سَ & & \\
\hline 67.47 & 1.30 & 5.56 & 1.55 & 3.32 & لدرجة & إختبار دقة التمرير القصير \\
\hline 9.42 & 0.76 & 38.45 & 2.68 & 35.14 & متر & إختبار ركل كرة ثابتَّة لأبعد مسافة \\
\hline 12.82 & 1.11 & 5.10 & 2.20 & 5.85 & ثانية & اختبار الجرى بالكرة فى خط مستقيم (25م) \\
\hline 9.01 & 2.06 & 11.21 & 1.58 & 12.32 & ثانية & اختبار الجرى الزجز اجى بين الأقماع 20م \\
\hline
\end{tabular}

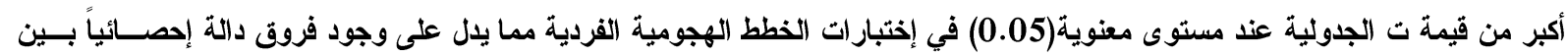

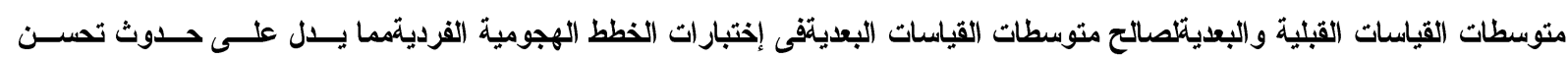
للمجموعة التجريبية قيد البحث.

$$
\text { جلول (12) }
$$

نسب التحسن بين متوسطات القياسات القبلية والبعديةفى بعض الخطط الهجومية الفردية لعينة البحث $19=\dot{0}$

يتضح من جدول (12) وجود نسب تحسن بين متوسطات القياس القبلى والقياس البعدى لصالح القياس البعدى فــى بعـض الخطـط لئل الهجومية القردية للعينة قيد البحث. 
يتضح من جدول (11) أن قيمة ت المحسوبة إنحصرت بين (2.64:4.38) بين متوســات

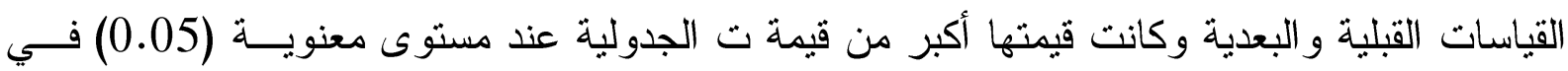
إختبار ات الخطط الهجومية الفردية مما يدل على وجود فروق دالة إحصائيا بين متوسطات القياسـات

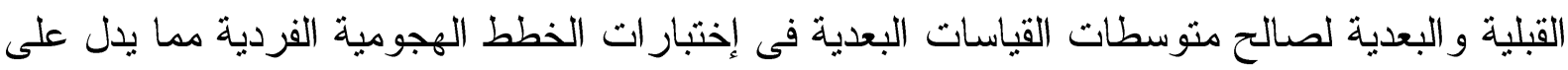
حدوث تحسن للمجموعة التجريبية قيد البحث.

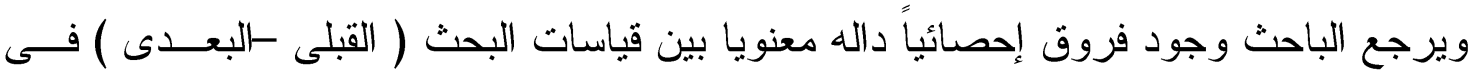
مستوى بعض الخطط الهجومية الفردية فى(إختبار دقة التمرير القصير ، إختبار ركل كرة ثابتة لأبعد

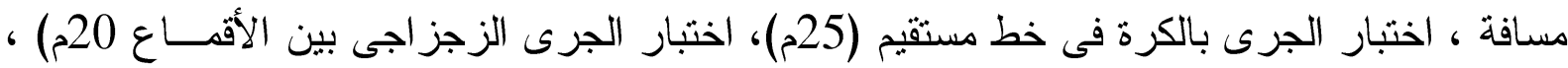

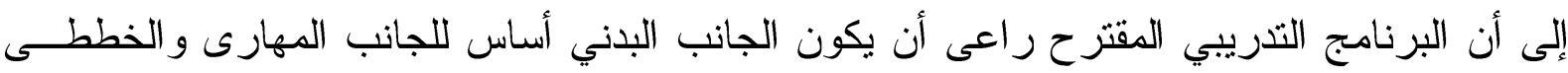

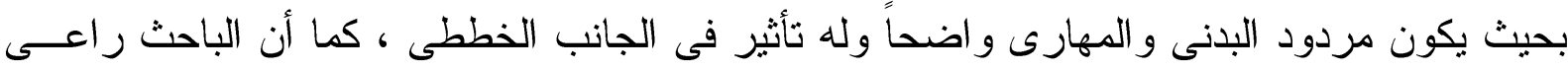

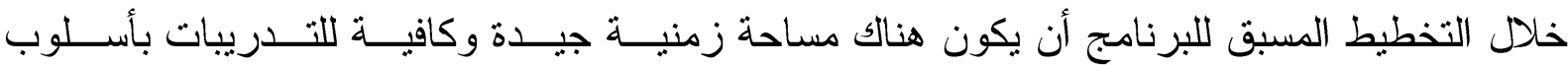

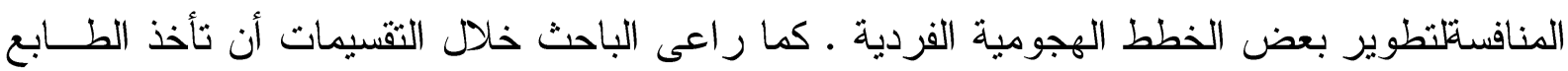

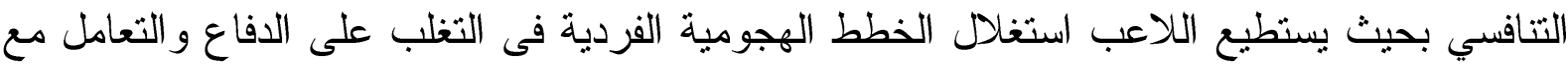
المنافسين ومن خلال مو اقف تشابه ما يحدث فى المبار اة.

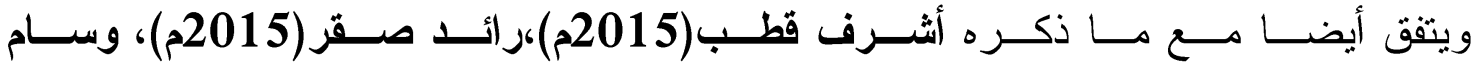
طعيمه(2016م)،أحمد حسن(2018م)أن البرنامج التدريبى المقترح و الذى تم وضعه وتقنينه أسنطاع

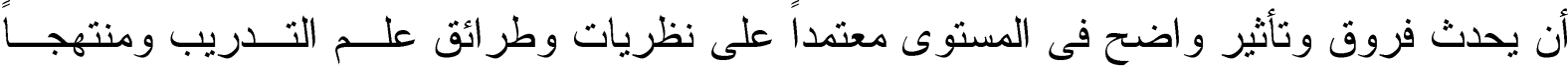
أسلوب متدرج ومناسب لطبيعة وخصائص المشاركين ، ولكى يتم النجاح للبرنامج التدريبى للناثــئين

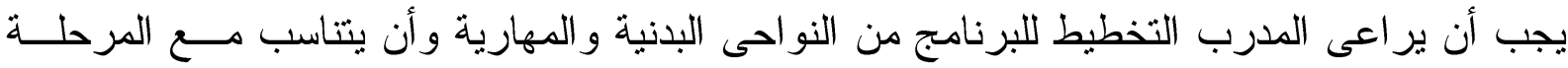
العمرية التى يخطط من أجلها ، وأن يتصف البرنامج بالثمولية و المتعة و الإثارة و السرور ، و وأن بــنت تحديد عدد مرات التدريب وزمن كل وحدة تدريبية. ويرى الباحث أن أسلوب المنافسة هو أسلوب لتطوير قابلية اللاعب لحـلـ مشــكلات اللعـبـ

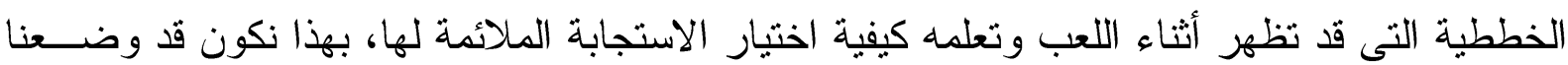

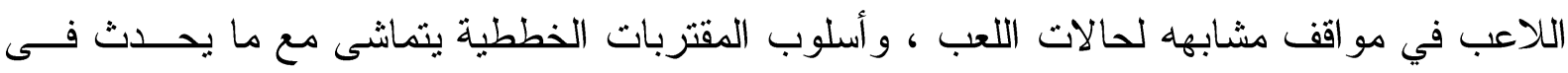

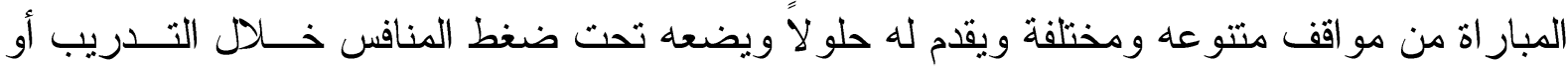
المبار اة وفى نفس ظروف المبار اة و هذا ما يتطابق ومتطلبات اللعب الحديث للناشئين، و هذه المو اقــــ

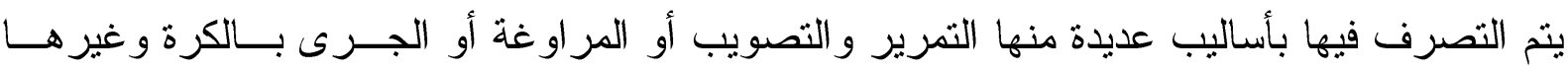
كوسائل للتغلب على دفاع الفرق المنافسة . 


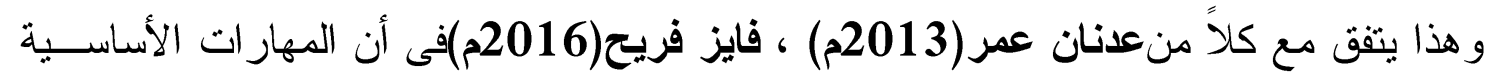

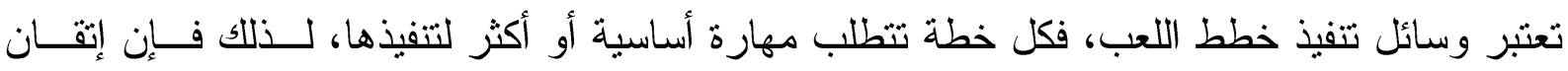

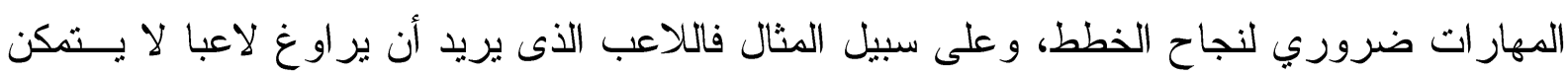

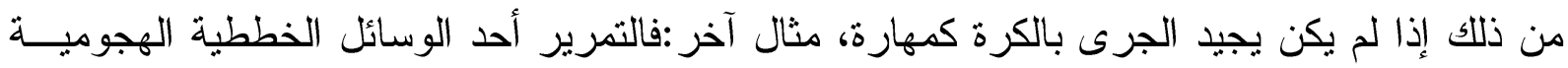

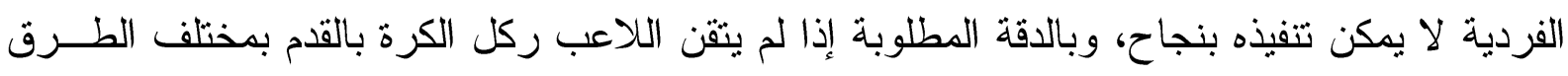

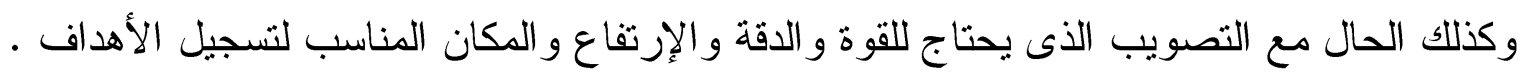
ويتفق أيضا مع كلاً من حسن أبو عبده (2008م)بريتــايون Pretayon (2013م) أن الندريب على المهار ات الأساسية يكون فى تمارين تشبه ما يحدث فى المباريات أو ما ير اد من اللاعبين تنفيذه

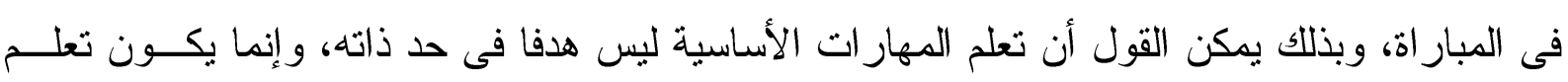

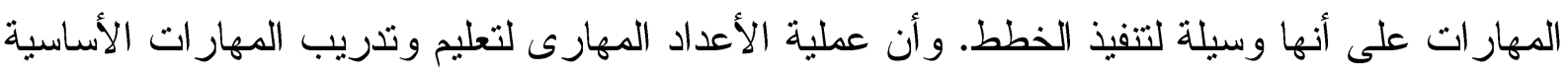

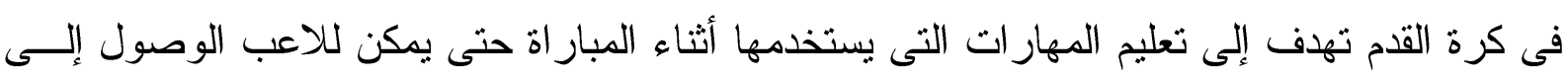

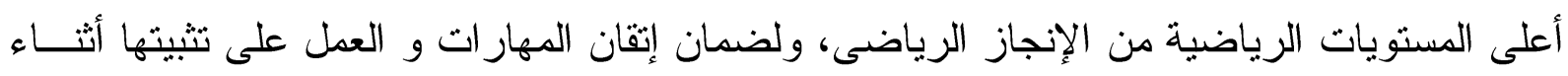

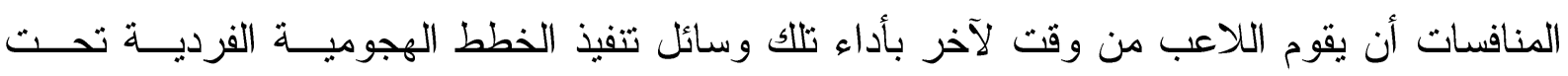

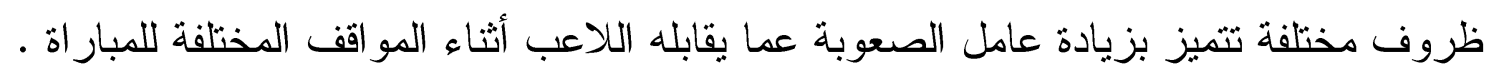

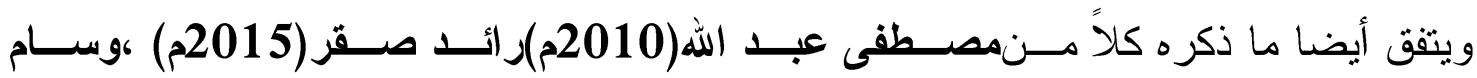

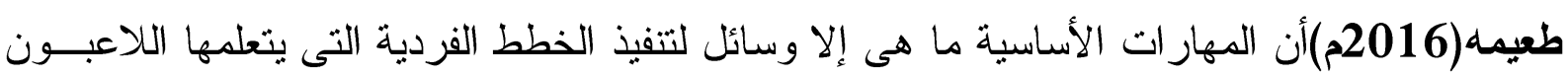

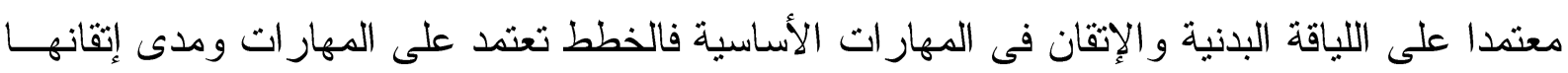

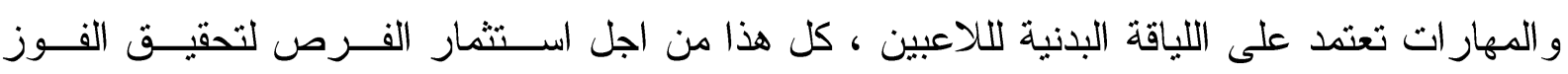
بالمبار اة. ويذلك بكون قـ تحقى الفرض الأول

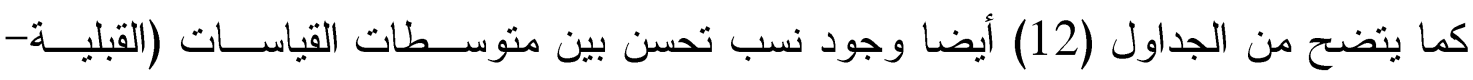

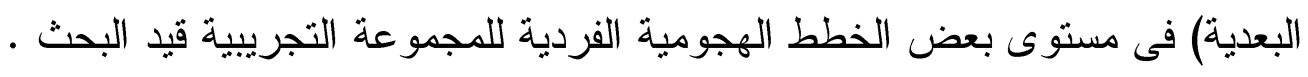

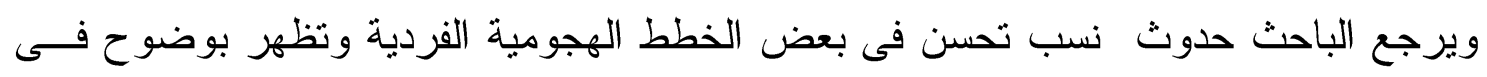

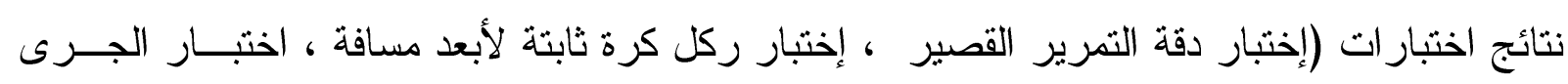

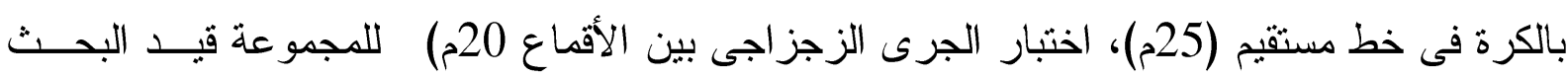

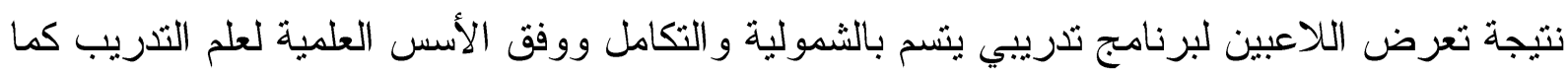

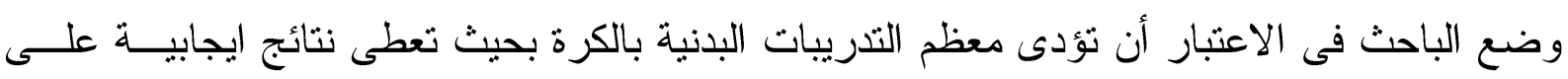

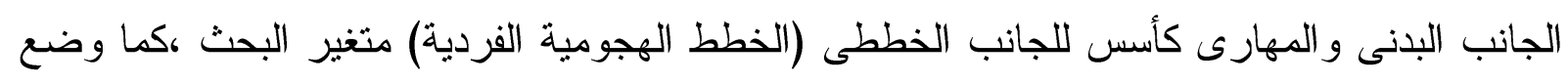

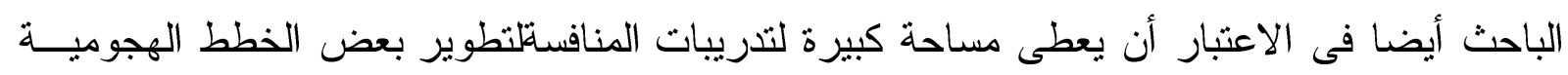


الفردية و التأكيد على استخدامها فى المواقف الفردية المناسبة لها فى مو اقف خططية مشابهه لما يحدث فى المبار اة. ويرى الباحث أن أسلوب المنافسة يعطى القدرة علـى اســتخدام المهـــار ات الأساســية وممارستها في حالات مشابهة لحالات اللعب.ولذلك لابد من توفير بيئـة للتـدريب علــى المهــار ات الأساسية وبنفس الوقت تطبيقها في حالات لعب و اقعية، كل ذلك بشكل متدرج ومنتظم لتحقيق الهـدف هـ المنشود وهو تحسين مستوى الناشئى وتطويره ليكون قادرا على تحمل عبئ المبار اة.و هذا مـــــــــر ظهر نتائجه فى متوسطات القياس البعدى لعينة البحث من تحسن فى مستوى الخطط الهجومية الفردية عنه فى متوسطات القياس القبلى لعينة البحث ، كذلك قيام الباحث بوضــع الإعـــداد الخططـــي بجوانبــهـ

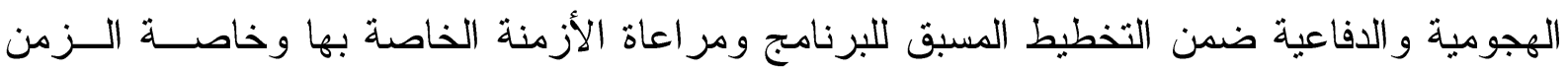

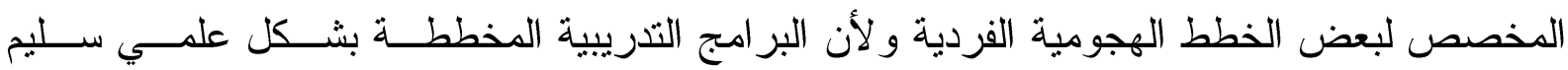
وتر اعى مبادئ علم التدريب الرياضى تعطى نتائج جيده ونسب تحسن و اضحة تظهر فى الفروق بين اللاعبين ، و هذا ما أحدث الفارق فى نسب التحسن بين متوسطات القياس البعدى عن متوسطات القياس القبلى.

و هذا يتفق مع كلاً عدنان عمر(2013م) ،رائد صــر (2015م) ، فــايز فـريح(2016م)أن البر امج التدريبية المخططة للناشئين فى كرة القدم وسيلة ضرورية للتقدم بحالة التـدريب الناشـئين ، حيث يحدد مضدون عملية التدريب بطريقة منظمة تؤدى إلى تقدم مستوى البر اعم ووصوله إلى أعلى

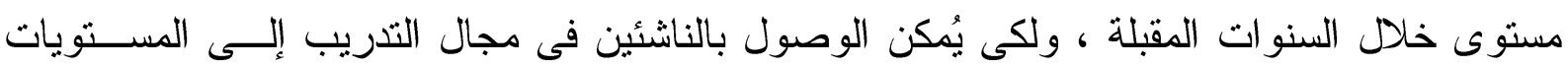
العالية فإن ذلك يتم خلال وقت طويل و لابد من التحكم فى هذا الوقت ولهذا نجد أن من الأهمية وضع خطط لفتر ات أقصر (سنوات- فترة - مرحلة - أسبوع) . ويتفق أيضا مع ما ذكره كلاً منعــنان عمسر(2013م) ،رائــــ صــر (2015م) ، فــايز فريع(2016م)، أحمد حسن(2018م)أن البر امج التدريبية المعطاة أعطت نسب تحسن مقبولــة بــين القياسات القبلية و البعدية للمجوعات قيد البحث ، وأدت إلى تحسن ملحوظ فى مستوى الناشئين بعـــ تعرضهم للبر امج التدريبية.ويـهذا بتحقق الفرض الثانحـ.

\section{• الإستخلاصات}

فى ضوء نتائج البحث وفى حدود العينة و المعالجات الإحصائية توصل الباحث للاستخلاصات التالية: وجود فروق داله إحصائياً بين متوسطات القياسات (القبلية.البعدية) فى مستوى بعض الخطـ ط الهجومية الفردية على التو الى (التمرير - التصويب - الجرى بالكرة- المراوغة) للمجموعــة التجريبية قيد البحث ولصالح القياس البعدى. 
وجود فروق فى معدلات نسب التحسن بين متوسطات القياسات (القبلية.البعدية) فى مســتوى بعض الخطط الهجومية الفردية على التوالى (التمرير - التصويب - الجرى بالكرة-المر اوغة) للمجموعة التجريبية قبد البحث ولصالح القياس البعدى.

\section{التوصيات}

فى ضوء الاستخلاصات تمكن الباحث من تحديد التوصيات التى يمكن الإستفادة منها كالتالى: استخدام أسلوب المنافسة فى بر امج تدريب الناشئين فى كرة القدم لما لها من تأثير واضح على الأداء للناشئين قبد البحث لهم وتعميمها فى المر احل العمرية المختلفة. إدر اج أسلوب المنافسات بأشكال مختلفة ومساحات مختلفةضمن محتويات البـــر امج التذريبيــة لناشئي كرة القدم لما لها من تأثير فعال فى تطوير مستويات الأداء للناشئين. مر اعاة خصائص المر احل السنية وطفرات النمو خلال بر امج التذريب ومحتو اها. ضرورة اهتمام المدربين بتدريبات أسلوبالمنافسةووضعها في تدريبات متدرجة الصعوبة مــن حيث التركيب بما يجعلها أكثر تشويقاً ونشابهاً لما يحدث في المباريات. تطبيق الار اسة على مر احل سنية أخرى وكذلك على مر اكز وخطوط مختلفة لضرورة التتوع من حيث أسلوب وشكل التدريبات لعدم شعور اللاعبين بالملل وكذلك وضـــع اللاعبـين فــي مو اقف اللعب التنافسية كي لا يفاجئ اللاعبين بتلك المو اقف أثثاء المبار اة.. تطبيث در اسات جديدة لمعرفة تأثير أسلوب المنافسة على الخطط الهجومية الجماعية أو الخطط الدفاعية أو على الواجبات الفردية لمر اكز اللعب المختلفة.

1. إبراهيم شعلان - عمرو أبو المجد (1996م): أسس بناء كرة القدم الشاملة، الطبعة الأولى، المكتبة الأكاديمبة، القاهرة .

2. أحمد حسن(2018م) : تأثير برنامج تعليمى باستخدام التدريبات التتافسية على مستوى اداء بعض مهار ات كرة القدم لتلاميذ المرحلة الاعدادية بمحافظة سوهاج، رسالة ماجستير ، كلية التربية الرياضية للبنات بفلمنج ، جامعة الإسكندرية.

3. أشرف قطب(2015م) :إستر اتيجية اللعب التنافسي وتأثثرها على مستوى أداء المهار ات المنهجية في كرة القدم لطلاب المرحلة الثانوية ، رسالة ماجستير ، كلية التربية الرياضية ، جامعة أسبوط. 
4. حسن أبو عبده (2008) :الإعداد المهارى للاعبي كرة القدم( النظرية و التطبيق) ، الطبعة الثامنة كمطبعة الإشعاع الفنية ، القاهرة.

5. رائد صقر(2015م) :تأثير برنامج تدريبي باستخدام تدريبات تتافسية على بعض القدرات البدنبة و المهارات الأساسيةلاى ناشئي كرة القدم في فلسطين ، رسالة ماجستير ، كلية التربية الرياضية للبنات بفلمنج ، جامعة الإسكندرية.

6. عدنان عمر(2013م) : تأثير استخدام الاسلوب التنافسي في تحسين مستوي اداء بعض المهارات

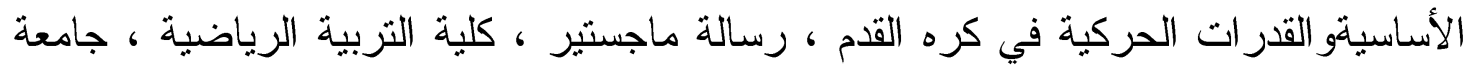

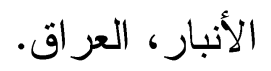

7. فايز فريح(2016م) :تأثير برنامج باستخدام تدريبات المواقف التنافسية على مستوى بعض الأل

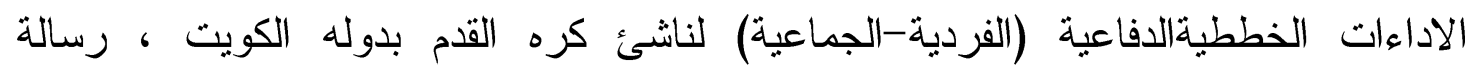
ماجستير ، كلية التربية الرياضية بقنا ، جامعة جنوب الو ادى.

8. محمد كثك- أمر الله البساطى (2000م): أسس الإعداد المهارى و الخططي فى كرة القدم . 9. مصطفى عبد الله(2010م) : دراسة مقارنة لوسائل تتفيذ الخطط الهجومية للاعبى خط الوسط فى بطولتي الأمم الإفريقية لكرة القدم 2006م - 2008م ، رسالة ماجستير غير منشورة، كلبة

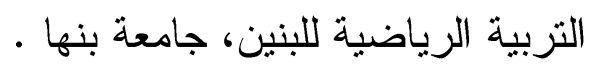
10.مفتى إبراهيم (1990): الهجوم في كرة القدم، دار الفكر العربي، القاهرة. 11.مفتى إبراهيم (1994): الجديد في الإعداد المهارى والخططي، دار الفكر العربي، القاهرة. 12.وسام طعيمه(2016م) : فعالية استخدام اسلوب التعلم التنافسي علي تحسين مسنوي اداء بعض فل المهار ات الأساسية في كره القدم لطلاب المرحلةالمتوسطة بالعراق، رسالة ماجستير ، كلية التزبية الرياضية للبنات بفلمنج ، جامعة الإسكندرية.

13- Pretayon.S.(2013) : A training program with A competition Drills Style on the Level of Some Offensive Tactics for Soccer Juniors . Science and sports magazine .Paris . France.

14- Pride. A. (2004) :Training Cycle Football Condition: Development of Theory \& Translation to Football Practice. Work paper . Ottawa. Canada .

15- Vladimir. L. .Ljach.W.. \&zzmuda.W. (2001) :The Prognostic Value of Coordination Motor Ability (CMA) Indices in the Evaluation of Development of Soccer Players Aged 16-19 Year Observation . Theoreticalof Physical education magazine . 1(8) 51-60 .Poland. 